\title{
The Problem-Based Learning Model and Students' Generic Skills of the Faculty of Teachers Training and Education the Universitas Siliwangi Tasikmalaya on the Animal Structure Course
}

\author{
Romy Faisal Mustofa ${ }^{1, a^{*}}$, A.D. Corebima ${ }^{2}$, Endang Suarsini ${ }^{2}$, Murni Saptasari ${ }^{2}$ \\ ${ }^{1}$ Department of Biology Education, Universitas Siliwangi Tasikmalaya, Indonesia \\ 2 Department of Biology Education, Universitas Negeri Malang, Jawa Timur, Indonesia \\ a syahla.aini@gmail.com \\ *Corresponding Author
}

How to Cite: Mustofa, R.,F.Corebima, A.D. Suarsini, E., Saptasari, M. (2019). The Problem-Based Learning Model and Students' Generic Skills of the Faculty of Teachers Training and Education the Universitas Siliwangi Tasikmalaya on the Animal Structure Course, International Journal for Educational and Vocational Studies, 1(1), 53-57. DOI: https://doi.org/10.29103/ijevs.v1i1.1466

\section{ARTICLE HISTORY}

Received: 13 March 2019

Revised: 28 April 2019

Accepted: 5 May 2019

KEYWORDS

Problem-Based learning

Generic skills

Animal Structure

Learning Outcomes

\section{ABSTRACT}

The aims of this study are to describe the learning process in animal structure courses and learning outcomes obtained by students of Biology Education Study Program, Teachers Training and Education Faculty, Siliwangi University Tasikmalaya after attending lectures. The research method used is survey data collection using a questionnaire. As many as 60 students who have attended and graduated in animal structure lectures in the 4th semester of the 2014/2015 academic year were used as research samples. Samples were taken using simple random sampling technique from a population of 90 students. Then the data obtained is processed using descriptive statistics. The results of the study show that students have an interest in animal structure courses, especially in practical activities. The implementation of learning in animal structure courses has not been carried out optimally. The indication is from the non-socialization of the learning model used by lecturers which has an impact on various generic skills that are not maximally trained and developed.

This is an open access article under the CC-BY-SA license.

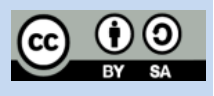

\section{INTRODUCTION}

Higher education should be able to organize a quality learning process that does not only develop the ability of its students to be limited to just one cognitive aspect, while aspects of skills are rarely touched. This has become one of the causes of the inability of higher education graduates to compete in the workforce or allow graduates to work in fields that are not in accordance with their educational qualifications. In accordance with the 2013 National Qualification Framework, college graduates must be able to apply their fields of expertise and utilize Science and Technology in their fields in solving problems and being able to adapt to the situation at hand, mastering certain theoretical concepts in general knowledge fields and theoretical concepts specifically in the field of knowledge in depth, and is able to formulate procedural problem solving. Referring to what was written in the 2013 Indonesian National Qualifications Framework (KKNI), in the implementation of learning in higher education, the skills aspect was one of the main indicators of the success of an educational process.
Based on this, various student skills should be trained and developed during the learning process, especially their generic skills. Generic skills become one of the basic capital for students, both during lectures and when they are in the workforce. Generic skills are employability skills used to apply the knowledge of Kamsah, (2004). This skill crosses all work fields in a horizontal direction and crosses all levels in the vertical direction. This definition is in line with that stated by the National Skill Task Force that generic skills are skills that cross a number of different jobs (Pumphey and Slater, 2002). Generic skills are also defined as skills and attributes for life and work (Kearns, Yeung et al., 2007. Furthermore, it is stated that generic skills are very useful for continuing education and career success (Yeung et al., 2007). given by some experts it can be concluded that generic skills are skills needed for various fields of work and life.

The high-grade point average (GPA) at the moment cannot be used as the main indicator for graduates of a university to be able to compete in the world of work. GPA 
only ranks 17 th in indicators and capabilities that reflect a person's quality (Irma, 2007). Other factors, such as communication skills, honesty, and integrity, ability to cooperate, analytical power, leadership, and others play an important role in the success of someone at work. From the results of the survey, it can be concluded that the world of work does not only require prospective workers who only have cognitive abilities but more in need of prospective workers who are able to apply their cognitive abilities in various forms of skills. the skills in question are generic skills or soft skills or ability skills.

The animal structure as one of the compulsory subjects and included in the Expertise Course Group (MKK) in the Biology Education Study Program, Faculty of Teacher Training and Education, Siliwangi University, Tasikmalaya. This course is used as one of the evaluation materials for learning in this study. The aim is to find out how the learning process takes place and the learning outcomes obtained after following the lecture process. This is based on the characteristics of this course which in its implementation is almost $90 \%$ carried out by practical activities. Theoretically, practicum courses should improve a variety of student generic skills. The question is how practicum activities in this course can have a better effect on student learning outcomes, especially on basic skills that are ready to be trained and developed.

Education in the $21^{\text {st }}$ century is about how to build the intelligence of students through the use of learning models that can create more meaningful learning by training various skills as one aspect of the success of a learning process. The learning model in question is Problem Based Learning (Tan, 2003). During this time the supporters and users of problem-based learning claimed the existence of various benefits obtained by using the learning model, both in terms of teaching and learning methodology. Problem-Based Learning promotes learning outcomes that are more profound than other learning models (Biggs, 1999; Aryani, 2019); encourage high level thinking; encourage self-regulated learning and the development of strategies and metacognitive skills (Hmelo-Silver, 2004; Tanjung, 2019; Nasir, 2018); creating a more stimulating learning environment; increase collaborative interaction between students and teachers; increase motivation; increase knowledge retention (Spencer \& Jordan, 1999).

Problem-Based Learning is better than the traditional approach (lecture-based learning) in terms of acquiring the generic skills needed for scientific careers, such as collaboration, information integration, critical thinking, communication skills and independent learning (Dolmans et al. 2005; Winarso, 2018). In short, there appears to be a close relationship between the opportunities provided by Problem-Based Learning to developing communication (teamwork and interpersonal), problem-solving and independent learning, and critical thinking skills in other generic skills for graduates that can be utilized during the lecture period and more away when graduates enter the workforce.

\section{METHODS}

The research method used surveys with the intention to describe how the learning process takes place and the learning outcomes obtained by students during and after attending the lecture process in animal structure courses. Data collection uses a questionnaire to reveal student opinions about the learning process in animal structure courses and learning outcomes especially on aspects of the skills they obtain after attending lectures. Furthermore, the data obtained were analyzed using descriptive statistics.

A total of 60 students who have attended and graduated in animal structure lectures in the fourth semester were used as research samples. Samples were taken using simple random sampling technique from a population of 90 students.

\section{RESULTS AND DISCUSSION}

\subsection{Students' Interest in Joining Lectures Animal structure}

A total of $46(76.7 \%)$ students stated that they were interested in attending lectures on microbiology courses. Full data is presented in Table. 1.

Table 1. Students' Interest in Animal Structure Courses

\begin{tabular}{|c|c|c|}
\hline Answers & Frequency & Percent \\
\hline Yes & 46 & 76,7 \\
\hline Not & 14 & 23,3 \\
\hline Total & 60 & 100 \\
\hline
\end{tabular}

Students' interest in animal structure courses is based on the type of lecture which is almost $75 \%$ carried out by practical activities. The remaining $25 \%$ stated that their interest in this course was due to the content of the material to be delivered.

\subsection{Students' Knowledge about Course Contents of Animal Structures Before Joining Lectures}

Regarding students' interest in animal structure courses, then they were asked questions about the knowledge of the subject matter of animal structure. The answers given from $36(60 \%)$ students stated that they previously knew about the subject matter of animal structure while the rest said they did not know the content to be presented in this course. The complete of the data is presented in Table. 2.

Table 2. Students' Knowledge about Course Contents of Animal Structures

\begin{tabular}{ccc}
\hline Answers & Frequency & Percent \\
\hline Yes & 36 & 60 \\
Not & 24 & 40 \\
Total & 60 & 100 \\
\hline
\end{tabular}




\subsection{Implementation of Learning with the Problem-Based Learning Model}

One of the focuses of this study is the implementation of the problem-based learning model during the lecture process in animal structure courses. The following is described regarding the implementation of learning using the model by asking questions according to the problem-based learning model syntax. The following are explained the stages of the learning process with a problem-based learning model.

\section{a. Orientation to the Problems}

The first step in implementing the problem-based learning model is to orient students to the problems. Based on the answers given, as many as $32(53.3 \%)$ students answered that the lecturers did not invite the focus on the problems to be delivered at the beginning of the lecture. Table. 3 completes the description above.

Table. 3. Problem-Oriented Learning

\begin{tabular}{ccc}
\hline Answers & Frequency & Percent \\
\hline Yes & 28 & 46,7 \\
Not & 32 & 53,3 \\
Total & 60 & 100 \\
\hline
\end{tabular}

\section{b. Organizing Students for Learning}

After the lecturer orientates students on the problems to be studied, then the lecturer organizes students through the formation of study groups. Similar to the previous step, for this step $32(53.3 \%)$ students answered that the lecturers did not form groups. The full data is presented in table 4.

Table. 4. Organizing Students for Learning

\begin{tabular}{ccc}
\hline Answers & Frequency & Percent \\
\hline Yes & 28 & 46,7 \\
Not & 32 & 53,3 \\
Total & 60 & 100 \\
\hline
\end{tabular}

\section{c. Helping Students' Investigations}

The third step in the problem-based learning model is that lecturers help students in the investigation process, especially in practical activities. The form of assistance provided can be in the form of giving motivation to students to gather various information needed in completing the results of experiments conducted by students, with the hope that students better understand what they are researching. For the questions asked, 45 (75\%) students answered "yes" and meant that the lecturer assisted in the investigation of students in each implementation of their learning. More information is presented in Table 5.

Table. 5. Helping Students' Investigations

\begin{tabular}{ccc}
\hline Answers & Frequency & Percent \\
\hline Yes & 45 & 75 \\
Not & 15 & 25 \\
Total & 60 & 100 \\
\hline
\end{tabular}

\section{d. Develop and present the work}

Regarding this question, all students answered that in the implementation of learning, especially in practical activities, they were required to be able to develop and present their work from the results of their investigations. Subsequent questions regarding the form of work the results of the investigation presented and based on the answers provided by the work of the investigation are only presented only in the form of an investigation report.

\section{e. Analyzing and Evaluating the Problem Solving Process}

The final step of the problem-based learning model is the lecturer analyzes and evaluates the problem-solving process. For this question, all students gave answers that the lecturer analyzed and evaluated the problem-solving process. As a follow-up study, it was also asked about animal structure material which received a greater portion in analyzing and evaluating problem-solving. Based on the results of the answers obtained, most students answered that the analysis and evaluation of problem-solving were mostly carried out on the subject of the evolution and development of vertebrate structures.

During the semester, the implementation of animal structure lectures in theoretical sessions, as well as practicum activities, was not realized by the students included in the lectures delivered using the problem-based learning model. This is viewed from the various answers conveyed by students related to the problem-based learning syntax. This is one of the duties and obligations of the teacher to always explain the learning model that will be used so that students will try to acquire knowledge and skills that can be trained, developed and produced through the use of the learning model.

\subsection{Generic Skills Trained in Theory Lectures}

To check students' knowledge about generic skills, in this study the researchers asked students questions about their knowledge of generic skills. Based on the data obtained, $81.7 \%$ of students stated that they had never heard the term generic skills. But when asked questions about what skills they acquired during and after attending lectures on animal structure courses, they gave answers that matched what they experienced even though they did not know that the skills they received were included in generic skills. The following table 6 shows some generic skills that are trained during the theoretical lecture activities in animal structure courses.

Table. 6. Generic Skills of Developed in the Theoretical Lectures Activities at the of Animal Structures Course

\begin{tabular}{lcc}
\hline \multicolumn{1}{c}{ Developed Skills } & Frequency & Percent \\
\hline Communication & 22 & 36,7 \\
Leadership & 6 & 10,0 \\
Cooperation & 32 & 53,3 \\
\multicolumn{1}{c}{ Total } & 60 & 100 \\
\hline
\end{tabular}


Based on the table, most students feel the cooperation skills between students and lecturers can be developed during the theoretical session lectures. This condition is felt by at least $32(53.3 \%)$ students. 22 (36.7\%) students admitted that their communication skills were developed and only $6(10 \%)$ students felt that their leadership skills could be developed.

Generic skills that can be developed during the lecture using the problem-based learning model are at least 4 types, namely organizational skills, interpersonal skills, cognitive skills and attitude (Lee and Edwards, 1997). While according to the Business Council of Australia there are eight types of generic skills needed in the area of financial and ICT work, including communication skills, thinking skills, learning skills, project management skills and priorities, collaboration skills and system understanding, skills in applying and using technology, leadership skills, and personal and interpersonal skills (Field, 2002; Ichsan, 2019).

\subsection{Generic Skills Trained in Practical Activities}

Activities of the practical lectures turned out to make a little difference to the development of generic skills of students. Often presenting the results of the investigation, or perhaps because of frequent collaborative collaboration in study groups, there is an increase in the development of generic skills especially in lead skills even though there is no significant improvement. The following are presented in table 7 data regarding generic skills that can be developed through practical activities.

Table. 7. Generic Skills Developed in Lectures Activities through

\begin{tabular}{lcc}
\multicolumn{3}{c}{ Practicum Activities in Animal Structure Courses } \\
\hline \multicolumn{1}{c}{ Developed Skills } & Frequency & Percent \\
\hline Communication & 18 & 30 \\
Leadership & 12 & 20 \\
Cooperation & 30 & 50 \\
\multicolumn{1}{c}{ Total } & 60 & 100 \\
\hline
\end{tabular}

As mentioned earlier, in practice activities leadership and communication skills have increased. This directly asks the writer (conducting an interview) to several students about how to do the practicum so that it can provide different skills development with theoretical lecture activities. The average student gives an answer that in practical activities the lecturer emphasizes collaborative cooperation in study groups so that they are indirectly trained to be able to communicate with group members when preparing investigative reports through group discussions. While trained leadership skills because some of the students are the chair of the study group whose job is to be able to lead the discussion in the group. These things cause differences in generic skills that can be developed in theoretical lectures with practical activities.

\section{CONCLUSION}

The results of the study concluded that lecturers did not or had not socialized the variation of learning models used during the learning process so that students did not have an understanding of the results expected from the use of the learning model. Students have an interest in animal structure courses based on knowledge of course content and practical activities that dominate lecture. This study also shows that only 3 generic skills can be trained and developed during the learning process, namely communication skills, leadership skills, and cooperation skills, for a variety of generic skills can be developed through theoretical lectures and practical activities. Each student only reports the results of his investigation in the form of a report on the results of the investigation.

\section{REFERENCES}

Aryani, R. (2019). Entrepreneurship Learning Model Based on Local Wisdom for Increasing Student Creative Business. Indonesian Journal of Contemporary Education, 1(1), 24-31.

Briggs, H. \& Hodgson, P. (2002). Generic Skills Development in Undergraduate Engineering Education in Australia. Deakin University.

Candy, Philip C. (2000). Reaffirming a proud tradition: Universities and lifelong learning. Active Learning in Higher Education 1; 101. Tersedia: http://www.sagepub.com. [22 April 2008].

Carrick Institute for Learning and Teaching in Higher Education. (2007). Assessing Generic Skills. Tersedia: http:// www.biaoassess.au.edu. [10 Maret 2008].

Curtis, D. \& Denton, R.(2003). The Authentic Performance-based Assessment of Problem-Solving. King William Road: NCVER.

Harris, K-L., Krause, K., Gleeson, D., Peat, M., Taylor, C. \& Garnett, R. (2007). Enhancing Assessment in the Biological Sciences: Ideas and resources for university educators. Tersedia: www.bioassess.edu.au. [8 Maret 2008].

H Jesse, Guiles, Kory, Ward-Cook Kory. (2006). Learning and Utilization of Generic Skills by Practitioners in the Field of Clinical Laboratory Science/Medical Technology. ProQuest Nursing \& Allied Health Source, Clinical Laboratory Science. No. 19, Vol. 2;

Halizah Awang, and Ishak Ramly. (2008). Creative Thinking Skill Approach Through Problem-Based Learning: Pedagogy and Practice in the Engineering Classroom. World Academy of Science, Engineering and Technology International Journal of Social, Management, Economics and Business Engineering Vol:2 No:4.

Ichsan, I. Z., Sigit, D. V., \& Miarsyah, M. (2019). Environmental Learning based on Higher Order Thinking Skills: A Needs Assessment. International Journal for Educational and Vocational Studies, 1(1), 21-24.

Irma, Dewi. (2007). Soft Skill ?. Pikiran Rakyat, Kamis 17 Juni 2007. Tersedia: http://aargantenk.multiply.com/journal/item /70/Soft_Skill. [1 September 2007].

Kamsah, M.Z., (2004). Developing Generic Skills in Classroom Environment: Engineering Student's Perspective.

Karen D. Konings, Reinout W. Wiers, Margaretha W. J. van de Wiel, and Henk G. Schmidt. (2005). Problem-Based Learning as a Valuable Educational Method for Physically Disabled Teenagers ?The Discrepancy Between Theory and Practice. Journal of Developmental and Physical Disabilities, Vol. 17, No. 2.

M. Carrió a , P. Larramona a , J.E. Baños a \& J. Pérez. (2011). The Effectiveness Of The Hybrid Problem-Based Learning Approach In 
The Teaching Of Biology: A Comparison With Lecture-Based Learning. Journal Of Biological Education, Volume 45, Number 4.

Motah, Mahendranath. (2007) Study of the Influence of Multiple Intelegence and the use of Soft Skill in Proyect Write-up among IT and Non-IT Students: A Research Paper. Proceedings of the 2007 Informing Science and IT Education Joint Conference. Tersedia: http://proceedings.informingscience.org/ InSITE2007/InSITE07p071-083Mota430.pdf. [1 September 2007].

Nasir, A. M., \& Hasmar, D. H. (2018). Relation between student's perceptions to the statistics lecturer in learning process with statistics achievement. Malikussaleh Journal of Mathematics Learning (MJML), 1(1), 9-12.

National Research Council. (2008). Research on Future Skill Demands: A Workshop Summary. Margaret Hilton, Rapporteur. Center for Education, Division of Behavioral and Social Sciences and Education. Washington, DC: The National Academies Press. Tersedia: http://www.nap.edu. [6 Maret 2008].

Oliver, R., Herrington, J., McLoughin, C. (1999). Exploring the Development of Students' Generic Skills Development in Higher Education Using A Web- based Learning Environment. Brisbane: ASCILITE'99.

Paquette, G. (2007). An Ontology and a Software Framework for Competency Modeling and Management. Educational Technology \& Society, 10 (3), 1-21.

Professional Standard's Council. 2004. The Nature of Soft Skill. Tersedia: http://www.lawlink.nsw.gov.au/lawlink. [1 Maret 2008].

Pumphrey, J. \& Slater, J. (2002). An Assessment of Generic Skill Needs. Notingham: Department for Education and Skills.

Rahman, T.,Rustaman, N., Syaodih, N.,Poedjiadi, A.(2008). Profil Kemampuan Generik Awal Calon Guru dalam Membuat Perencanaan pada Praktikum Fisiologi Tumbuhan. Educare Online $(2 ; 2)$.

Rakhshanda Tayyeb. (2013). Effectiveness of Problem Based Learning as an Instructional Tool for Acquisition of Content Knowledge and Promotion of Critical Thinking Among Medical Students. Journal of the College of Physicians and Surgeons Pakistan, Vol. 23 (1): 42-46.

Riccardo Natoli, Beverley Jackling and Lalith Seelanatha. (2014). The impact of instructor's group Management strategies on students' Attitudes to group work and generic Skill development. Pedagogies: An International Journal, vol. 9, No. 2, 116-132.

Rosalind Murray-Harvey a, David D. Curtis a, Georgina Cattley a \& Phillip T. Slee (2005). Enhancing Teacher Education Students' Generic Skills Through Problem-Based Learning. Teaching Education. Volume 16, Number 3.

Spencer, Lyle M. \& Spencer, Signe M. (1993). Competence at Work. New York: John Wiley and Sons.

Tanjung, R. F. (2019). Answering the Challenge of Industrial Revolution 4.0 Through Improved Skills Use of Technology College. International Journal for Educational and Vocational Studies, 1(1), 11-14.

Winarso, W. (2018). Authentic Assessment for Academic Performance; Study on the Attitudes, Skills, and Knowledge of Grade 8 Mathematics Students. Malikussaleh Journal of Mathematics Learning (MJML), 1(1), 1-8.

UPI. (2007). Kurikulum Ketentuan Pokok dan Struktur Program 2007. Bandung: UPI.

Yeung, A. S.,Ng, Chistina, Liu, W,P.(2007). Generic Capabilities for Lifelong Education: Conceptualization and Construct Validity. Australian Association for Research in Education, Fremantle, November 2007. 